\title{
Influence of "diagnostic delay" upon cancer survival: an analysis of five tumour sites
}

\author{
Miquel Porta, Manuel Gallén, Núria Malats, Josep Planas
}

\begin{abstract}
Study objective-The aim was to assess the relationship between survival, tumour stage, and the interval from first symptom to diagnosis (SDI, or duration of symptoms).
\end{abstract}

Design-This was a retrospective follow up study of a cohort of patients registered in the tumour registry of the Hospital del Mar (Barcelona).

Setting-Hospital based tumour registry, with patients derived mainly from the City of Barcelona.

Participants-1247 cases of lung, breast, stomach, colon, or rectal cancer were analysed using survival curves and Cox proportional hazards regression. Subjects (mean age 63.6 years) were followed for a median length of 12.9 months after diagnosis. At the time of diagnosis one fourth of patients had disseminated disease.

Measurements and main results-Based on clinical records, a physician registered the onset time of the first symptom attributable to cancer (from which the SDI is computed), as well as the tumour stage at diagnosis. Other measurements followed standard tumour registry procedures. Overall, the crude mean SDI was 5.15 months (SD 8.03, median $2 \cdot 03$ ); only $24 \cdot 5 \%$ of cases had an SDI less than a month. Crude mean SDIs by anatomical site were as follows: lung cancer 3.07 months; breast 7.44; stomach 5.34; colon 5.74; rectum 5.03. Tumour extension did not appear to be significantly influenced by SDI, only breast cancer showing a distinct pattern of increased extension with increasing SDI. As expected, the probability of survival decreased monotonically with increasing stage in all sites. Tumour site was also a significant predictor of survival, which at one year ranged from $93 \%$ for breast cancer to $28 \%$ for lung cancer. However, a longer SDI tended sometimes to be associated with a better chance of survival, a fact that was most apparent in colon cancer. All Cox proportional hazards models showed a consistent picture: SDI was not a significant predictor of survival (age and sex adjusted hazard ratios ranging from 0.97 to 1.01 ), neither was sex; age did predict survival, and so did site and stage.

Conclusions-The results provide further evidence of a very weak relationship between SDI and tumour stage at diagnosis (except for breast cancer), and between SDI and survival, thus emphasising some limitations within which early clinical detection operates. They also suggest that in addition to reflecting patient and physician behaviour, as well as the functioning of the health system, SDI may be influenced by the biological behaviour of the tumour.

Conflicting results have been found in studies analysing the influence upon cancer prognosis of the time interval between onset of symptoms and diagnosis (SDI, or duration of symptoms). Some authors show ${ }^{1-6}$ or imply $^{7-9}$ that a relationship exists (eg, the shorter the SDI, the more localised the tumour and the longer the survival), whereas others $^{10-26}$ have found that long SDIs are not necessarily associated with more disseminated disease or with increased mortality. Indeed, for some cancers it is often accepted: (1) that they are curable if discovered early in the preclinical course, (2) that delay in diagnosis is a most significant factor in poor prognosis, and (3) that the extent of spread at the time of diagnosis and treatment is closely correlated with prognosis. ${ }^{2728}$

Nevertheless, the three points need not be equally true. Furthermore, while the degree of differentiation is not always well correlated with the degree of invasiveness or the rapidity of growth, ${ }^{28-30}$ a shorter clinical history is not uncommonly associated with poorly differentiated cancers. ${ }^{13} 14$ 28-34

Hence, it seems crucial to note that uses of the concept of early detection may hide two very different phenomena: (a) a limited spread of the tumour at the time of diagnosis, and (b) a short time interval between clinical onset of disease and diagnosis. Whereas the latter cannot be assumed to guarantee finding a localised disease, biological characteristics of the tumour, host resistance, and host-tumour interaction do appear to significantly explain its growth, 29 30 35-37 and may thus be of greater prognostic importance than the length of symptomatic illness.

However, few epidemiological studies have formally analysed the influence of the duration of symptoms upon cancer survival, maybe because-as Morrison expressed it-"there is a compelling intuitive appeal to the idea that earlier treatment must work; it seems inconceivable that there might be no gain in finding disease early."34

The primary goal of the present study was to assess the relationship between SDI, tumour stage, and survival in five cancer anatomical sites: lung, breast, stomach, colon, and rectum. 
Methods

Data from the tumour registry of the Hospital del Mar (TRHM), a 450 bed teaching hospital primarily serving a low income area in Barcelona, were used in the present study. A detailed description of TRHM ${ }^{38}$ and other preliminary results $^{39}$ have been previously published. In summary, this is a hospital based tumour registry initiated in 1978 and currently including about 4000 neoplasms. It follows the data collection procedures established by a regional collaborative Oncology group. ${ }^{40}$ All information is obtained from clinical records. Over $95 \%$ of tumours are microscopically confirmed, $6.8 \%$ are of unknown origin, and $5 \%$ are double neoplasms; $96.8 \%$ of cases are residents of the city of Barcelona.

Data collection, quality assurance and computerisation are all conducted on site by a research fellow under the supervision of an oncologist and an epidemiologist. The SDI is computed from the date of histological diagnosis and the first symptom attributable to cancer, as recorded in clinical notes. Stage is classified as local, regional, or disseminated; tumours with regional dissemination are those with regional nodal involvement $(\mathrm{N}+)$ or invasion of structures surrounding the primitive tumour. In order to achieve a minimum amount of follow up, we only selected cases registered between 1978 and 1987. Analysis was also restricted to the five most common tumours: lung, breast, colon, rectum, and stomach. Of the recorded cases, $3.2 \%$ were excluded from the analysis since the SDI was unspecified.

To assess the relationship between a categorical variable with more than two levels and a nonnormally distributed quantitative variable the Kruskal-Wallis test was used. Age and sex adjusted geometric means of SDI were obtained for each site and stage by least squares linear regression of the natural logarithmic transformation of SDI to the corresponding variables.

Table I Characteristics of cases, and interval from first symptom to diagnosis $(S D I)$, by primary tumour site.

\begin{tabular}{|c|c|c|c|c|c|c|c|}
\hline & Variable & Breast & Stomach & Rectum & Colon & Lung & Total \\
\hline \multirow[t]{2}{*}{1} & $\begin{array}{l}\text { No of cases } \\
\text { Follow up (median) } \\
\text { Uncensored (\%) } \\
\text { Sex (\% females) } \\
\text { Age (mean, years) } \\
\text { Stage }(\%)\end{array}$ & $\begin{array}{r}335 \\
36 \cdot 9 \\
37 \cdot 0 \\
100 \\
57 \cdot 9\end{array}$ & $\begin{array}{r}174 \\
9 \cdot 0 \\
64 \cdot 4 \\
41 \cdot 3 \\
67 \cdot 3\end{array}$ & $\begin{array}{r}132 \\
11 \cdot 1 \\
55 \cdot 3 \\
43 \cdot 2 \\
69 \cdot 9\end{array}$ & $\begin{array}{r}196 \\
17 \cdot 9 \\
50 \cdot 0 \\
47 \cdot 9 \\
64 \cdot 5\end{array}$ & $\begin{array}{r}410 \\
5 \cdot 9 \\
83 \cdot 9 \\
8 \cdot 5 \\
64 \cdot 4\end{array}$ & $\begin{array}{r}1247 \\
12 \cdot 9 \\
60 \cdot 2 \\
47 \cdot 6 \\
63 \cdot 6\end{array}$ \\
\hline & $\begin{array}{l}\text { Local } \\
\text { Regional } \\
\text { Disseminated } \\
\text { Unspecified }\end{array}$ & $\begin{array}{r}38 \cdot 5 \\
43 \cdot 0 \\
13 \cdot 1 \\
5 \cdot 4\end{array}$ & $\begin{array}{l}23 \cdot 6 \\
39 \cdot 1 \\
24 \cdot 7 \\
12 \cdot 6\end{array}$ & $\begin{array}{r}40 \cdot 1 \\
33 \cdot 3 \\
19 \cdot 7 \\
6 \cdot 8\end{array}$ & $\begin{array}{r}39 \cdot 3 \\
39 \cdot 3 \\
18 \cdot 9 \\
2 \cdot 5\end{array}$ & $\begin{array}{r}18 \cdot 8 \\
34 \cdot 9 \\
40 \cdot 7 \\
5 \cdot 6\end{array}$ & $\begin{array}{r}30 \cdot 2 \\
38 \cdot 2 \\
25 \cdot 4 \\
6 \cdot 2\end{array}$ \\
\hline 2 & $\begin{array}{l}\text { Crude SDI }{ }^{\mathrm{a}} \\
\text { Mean } \\
\text { SD } \\
\text { Median } \\
\% \geqslant 5 \text { months } \\
\text { Q3-Q1 }{ }^{\mathrm{b}}\end{array}$ & $\begin{array}{c}7 \cdot 44 \\
11 \cdot 19 \\
3 \cdot 02 \\
35 \cdot 8 \\
7 \cdot 97\end{array}$ & $\begin{array}{c}5 \cdot 34 \\
7 \cdot 80 \\
2 \cdot 98 \\
28 \cdot 7 \\
4 \cdot 92\end{array}$ & $\begin{array}{c}5 \cdot 74 \\
8 \cdot 47 \\
2 \cdot 98 \\
32 \cdot 6 \\
4 \cdot 98\end{array}$ & $\begin{array}{c}5 \cdot 03 \\
6 \cdot 84 \\
2 \cdot 97 \\
30 \cdot 1 \\
5 \cdot 04\end{array}$ & $\begin{array}{c}3.07 \\
3 \cdot 75 \\
2 \cdot 00 \\
16 \cdot 1 \\
3 \cdot 93\end{array}$ & $\begin{array}{r}5 \cdot 15 \\
8 \cdot 03 \\
2 \cdot 03 \\
27 \cdot 1 \\
4 \cdot 00\end{array}$ \\
\hline 3 & $\begin{array}{l}\text { Age adjusted SDI by s } \\
\text { Females } \\
\text { Males }\end{array}$ & $\begin{array}{c}x \text { (geome } \\
3.08 \\
-\end{array}$ & $\begin{array}{c}\left(\text { mean }^{\mathrm{a}}\right. \\
2 \cdot 59 \\
2 \cdot 83\end{array}$ & $\begin{array}{l}3.01 \\
3.02\end{array}$ & $\begin{array}{l}2 \cdot 62 \\
2 \cdot 36\end{array}$ & $\begin{array}{l}1.99 \\
1.87\end{array}$ & $\begin{array}{l}2 \cdot 62 \\
2 \cdot 57\end{array}$ \\
\hline 4 & $\begin{array}{l}\text { Age and sex adjusted S } \\
\text { Local } \\
\text { Regional } \\
\text { Disseminated } \\
\text { Unspecified } \\
\text { Total }\end{array}$ & $\begin{array}{c}\text { DI by st: } \\
2 \cdot 54 \\
3 \cdot 39 \\
4 \cdot 24 \\
2 \cdot 03 \\
3 \cdot 04\end{array}$ & $\begin{array}{l}\text { (geometric } \\
2 \cdot 36 \\
3 \cdot 08 \\
2 \cdot 89 \\
2 \cdot 51 \\
2 \cdot 73\end{array}$ & $\begin{array}{r}\text { mean })^{\mathrm{a}} \\
2 \cdot 77 \\
3.66 \\
2.46 \\
3.09 \\
3.02\end{array}$ & $\begin{array}{l}2 \cdot 43 \\
2 \cdot 41 \\
2 \cdot 86 \\
1 \cdot 70 \\
2 \cdot 48\end{array}$ & $\begin{array}{l}1 \cdot 72 \\
2.01 \\
1.92 \\
2 \cdot 68 \\
1.89\end{array}$ & $\begin{array}{l}2 \cdot 31 \\
2 \cdot 82 \\
2 \cdot 76 \\
2 \cdot 51 \\
2 \cdot 51\end{array}$ \\
\hline
\end{tabular}

\footnotetext{
a In months.
b $\mathrm{Q} 3-\mathrm{Q} 1=$ the difference between the upper quartile (or 75th percentile) and the lower
} quartile (or 25 th percentile)
Survival curves were estimated by the KaplanMeier method ${ }^{41}$ and compared by means of a generalisation of the non-parametric Wilcoxon test to censored data for the case of variables with two categories, ${ }^{42}$ and of a generalised KruskalWallis test for comparing three or more samples. ${ }^{43}$ Cox proportional hazards regression ${ }^{44}$ was used to estimate the hazard rate of SDI (the hypothesised primary explanatory variable), adjusted for age, sex, and tumour site and stage (the potential confounding and effect modifying variables). Hazard ratios were used to describe the relationship between the explanatory variable and survival time. Hazard ratios are the ratios of the hazard rates for values of variables unfavourable to survival to those of variables favourable to survival; the measure can be interpreted as the approximate instantaneous relative risk associated with a particular factor, either continuous (eg, SDI, age) or categorical (eg, regional $v$ localised tumour stage). Computations were performed by using Pecan $^{45}$ and the SAS PHGLM procedure developed by Harrell ${ }^{46}$; the two programs yielded

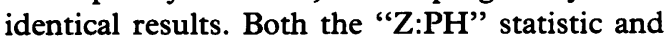
inspection of plots of $\log$ minus log survival function against time were used to check the proportional hazards assumption. ${ }^{46}$ The significance level was established at 0.05 and all $\mathrm{p}$ values are two tailed.

\section{Results}

The 1247 subjects in this study were followed for a median length of 12.9 months after diagnosis, with a mean of 23.7 months (table I). Follow up varied from a median of 36.9 months for breast cancer cases, of whom $37 \%$ died, to a median of 5.9 months for lung cancer cases, of whom $84 \%$ died. Only 67 cases (5.4\%) were lost to follow up, and all but 215 patients $(17 \cdot 2 \%)$ were followed for two years or to death. Overall, $751(60.2 \%)$ members of this dynamic cohort died during follow up and were thus uncensored. No anatomical site showed statistically significant differences between sexes in the proportion of uncensored cases.

Mean age was 63.6 years (SD 12.9, median 64.4). One fourth of cases had disseminated disease at the time of diagnosis. As expected, differences in stage distributions among anatomic sites were statistically significant $\left(\chi^{2}{ }_{[12]}=121\right.$, $\mathrm{p}<0.0001$ ); lung and to a lesser extent stomach, showed more disseminated patterns.

As shown in section 2 of table $I$, the crude mean SDI was rather large, $5 \cdot 15$ months (SD 8.03, median 2 months). Only $24.5 \%$ of cases had an SDI less than a month; $75 \%$ of cases had an SDI less than 5.02 months. Interestingly, breast cancer showed the largest SDI and lung cancer the shortest interval, with colorectal and gastric cancer presenting intermediate values $(p<0.0001)$. Sex had barely any influence upon SDI (section 3, table I).

Tumour extension at diagnosis did not appear to be significantly influenced by the duration of symptoms (section 4, table I). Only breast cancer showed a distinct pattern of increased extension with increasing SDI; the differences in SDI between the local and regional stages $(p=0.036)$, and between the local and disseminated stages 
$(p=0.01)$ reached statistical significance. No other site showed statistically significant differences among stages. The overall age and sex adjusted SDI for lung cancer is significantly lower than the corresponding value in each of the four other anatomical sites $(p<0.01$ in all cases).

As can be seen in table II, the probability of survival at one and at five years decreased monotonically with increasing stage in all sites. As expected, tumour site was also a significant predictor of survival, which at one year ranged from $93 \%$ for breast cancer to $28 \%$ for lung cancer.

Cases were next divided in every site/stage subgroup according to whether their SDI was above or below the site median SDI (previously shown in table I), and their median survival was computed (table II); obviously, when over $50 \%$ of cases in a subgroup were alive the latter could not be estimated. For example, $50 \%$ of cases with local stomach cancer whose SDI was below 2.98 months (the group median SDI) survived $\geqslant 29$ months; but those whose SDI was above the group median SDI survived $\geqslant 62$ months. Surprisingly a longer SDI tended sometimes to be associated with a better chance of survival. This was most apparent in colon cancer, where all subgroups above the median SDI yielded longer survival times than their counterparts below the median SDI. The phenomenon was also observed in localised breast cancer, localised and regional gastric cancer, regional and disseminated rectal cancer, as well as in disseminated lung cancer. While some of the differences in survival were minor and most could be due to chance, the lack of a consistent, positive relationship between

Table II Proportion of uncensored (dead) cases, probability of survival at one and at five years, and $50 \%$ percentile survival for cases with interval from first symptom to diagnosis (SDI) below and above the site group median SDI.

\begin{tabular}{|c|c|c|c|c|c|c|}
\hline Site/stage & $\begin{array}{l}\text { Uncensored } \\
(\%)\end{array}$ & $P_{1}$ & $P_{5}$ & $\begin{array}{l}\text { SDI < median } \\
\text { survival }^{\mathrm{a}}(n)\end{array}$ & $\begin{array}{l}S D I \geqslant \text { median } \\
\text { survival }^{2}(n)\end{array}$ & p value \\
\hline $\begin{array}{l}\text { Breast } \\
\text { Local } \\
\text { Regional } \\
\text { Disseminated } \\
\text { Total }\end{array}$ & $\begin{array}{l}22 \cdot 5 \\
40 \cdot 3 \\
70 \cdot 5 \\
37 \cdot 0\end{array}$ & $\begin{array}{l}0.975 \\
0.932 \\
0.779 \\
0.928\end{array}$ & $\begin{array}{l}0 \cdot 760 \\
0 \cdot 551 \\
0 \cdot 256 \\
0 \cdot 600\end{array}$ & $\begin{array}{l}84(72) \\
65(64) \\
36 \quad(16) \\
72(152)\end{array}$ & $\begin{array}{ll}\mathrm{nr} & (57) \\
65 & (80) \\
19 & (28) \\
77(165)\end{array}$ & $\begin{array}{l}0 \cdot 107 \\
0.699 \\
0.063 \\
0 \cdot 372\end{array}$ \\
\hline $\begin{array}{l}\text { Stomach } \\
\text { Local } \\
\text { Regional } \\
\text { Disseminated } \\
\text { Total }\end{array}$ & $\begin{array}{l}41 \cdot 5 \\
64 \cdot 7 \\
83 \cdot 7 \\
64 \cdot 4\end{array}$ & $\begin{array}{l}0.790 \\
0.557 \\
0.367 \\
0.563\end{array}$ & $\begin{array}{l}0 \cdot 418 \\
0 \cdot 197 \\
0 \cdot 046 \\
0 \cdot 207\end{array}$ & $\begin{aligned} 29 & (24) \\
11 & (28) \\
9 & (21) \\
18 & (73)\end{aligned}$ & $\begin{aligned} 62 & (17) \\
17 & (40) \\
4 & (22) \\
14 & (79)\end{aligned}$ & $\begin{array}{l}0.356 \\
0.982 \\
0.249 \\
0.509\end{array}$ \\
\hline $\begin{array}{l}\text { Rectum } \\
\text { Local } \\
\text { Regional } \\
\text { Disseminated } \\
\text { Total }\end{array}$ & $\begin{array}{l}37 \cdot 7 \\
63 \cdot 6 \\
73 \cdot 1 \\
55 \cdot 3\end{array}$ & $\begin{array}{l}0 \cdot 709 \\
0.603 \\
0.502 \\
0.626\end{array}$ & $\begin{array}{l}0.491 \\
0 \cdot 266 \\
0 \cdot 164 \\
0 \cdot 322\end{array}$ & $\begin{aligned} \mathrm{nr} & (28) \\
15 & (16) \\
5 & (16) \\
18 & (60)\end{aligned}$ & $\begin{array}{ll}29 & (25) \\
19 & (28) \\
16 & (10) \\
21 & (63)\end{array}$ & $\begin{array}{l}0.669 \\
0.968 \\
0.166 \\
0.756\end{array}$ \\
\hline $\begin{array}{l}\text { Colon } \\
\quad \text { Local } \\
\text { Regional } \\
\text { Disseminated } \\
\text { Total }\end{array}$ & $\begin{array}{l}25 \cdot 9 \\
57 \cdot 1 \\
78 \cdot 4 \\
50 \cdot 0\end{array}$ & $\begin{array}{l}0.907 \\
0.767 \\
0.451 \\
0.762\end{array}$ & $\begin{array}{l}0 \cdot 583 \\
0 \cdot 270 \\
0 \cdot 116 \\
0 \cdot 364\end{array}$ & $\begin{aligned} 57 & (34) \\
16 & (44) \\
9 & (17) \\
28 & (95)\end{aligned}$ & $\begin{array}{ll}\text { nr } & (43) \\
22 & (33) \\
10 & (20) \\
34 & (96)\end{array}$ & $\begin{array}{l}0.350 \\
0 \cdot 243 \\
0 \cdot 777 \\
0 \cdot 172\end{array}$ \\
\hline $\begin{array}{l}\text { Lung } \\
\text { Local } \\
\text { Regional } \\
\text { Disseminated } \\
\text { Total }\end{array}$ & $\begin{array}{l}64 \cdot 9 \\
86 \cdot 7 \\
89 \cdot 2 \\
83 \cdot 9\end{array}$ & $\begin{array}{l}0 \cdot 512 \\
0 \cdot 279 \\
0 \cdot 164 \\
0 \cdot 278\end{array}$ & $\begin{array}{l}0.238 \\
0.043 \\
0.000 \\
0.067\end{array}$ & $\begin{aligned} 14 & (40) \\
6 & (63) \\
4 & (71) \\
6 & (174)\end{aligned}$ & $\begin{array}{r}12(37) \\
6 \quad(80) \\
5(96) \\
6(213)\end{array}$ & $\begin{array}{l}0 \cdot 780 \\
0 \cdot 507 \\
0 \cdot 694 \\
0 \cdot 282\end{array}$ \\
\hline $\begin{array}{l}\text { Total } \\
\quad \text { Local } \\
\text { Regional } \\
\text { Disseminated } \\
\text { Total }\end{array}$ & $\begin{array}{l}36 \cdot 1 \\
62 \cdot 6 \\
83 \cdot 3 \\
60 \cdot 2\end{array}$ & $\begin{array}{l}0.809 \\
0.625 \\
0.340 \\
0.605\end{array}$ & $\begin{array}{l}0 \cdot 554 \\
0 \cdot 280 \\
0 \cdot 070 \\
0 \cdot 307\end{array}$ & $\begin{array}{r}57(197) \\
16(213) \\
6(155) \\
17(565)\end{array}$ & $\begin{array}{r}\mathrm{nr}(180) \\
21(263) \\
7(162) \\
21(605)\end{array}$ & $\begin{array}{l}0.006 \\
0 \cdot 429 \\
0 \cdot 484 \\
0 \cdot 130\end{array}$ \\
\hline
\end{tabular}

$P_{1}=$ probability of survival at one year.

$\mathrm{P}_{5}=$ probability of survival at five years.

a survival of $50 \%$ percentile of subgroup cases (median survival, in months); cases with unspecified extensions are excluded.

Two tailed probability for the difference in survival distributions between subjects with SDI below and above the group median SDI.

$\mathrm{nr}=$ Median survival not yet reached (over $50 \%$ of cases were alive).

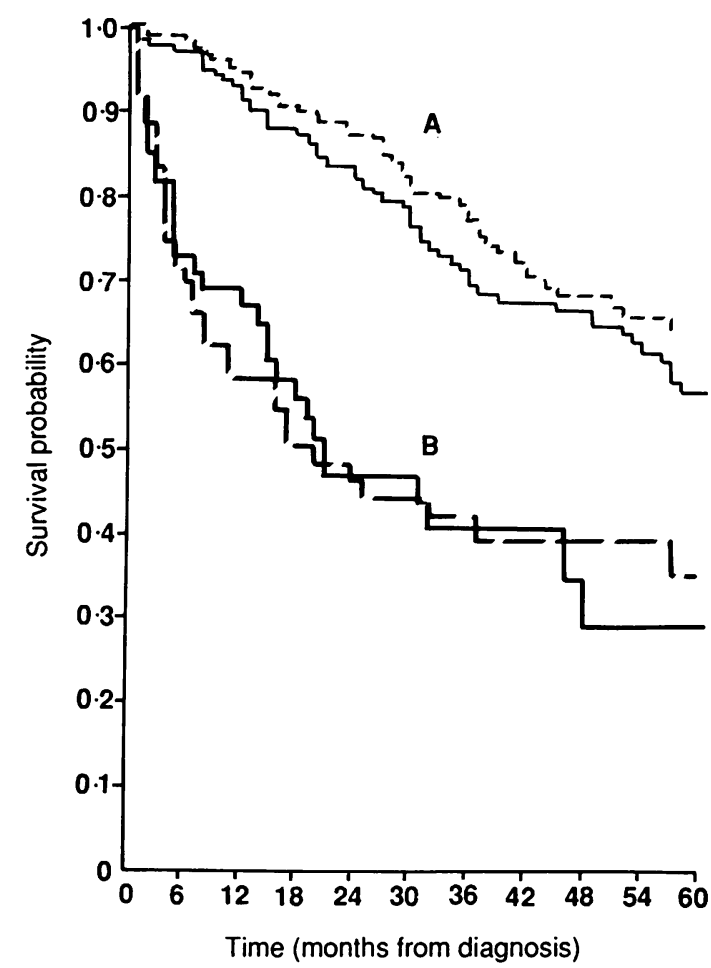

Survival distributions of cases below (interrupted line) and above (continuous line) the group median SDI for breast cancer $(A)$ and rectal $(B)$ cancer.

SDI and survival is unmistakable. Purely to illustrate this point, fig 1 depicts the survival distributions of breast and rectal cancer cases above and below each site group median SDI.

Results of Cox proportional hazards analysis appear in table III. All models show a consistent picture: SDI was not a significant predictor of survival (age and sex adjusted hazard ratios ranging from 0.97 to 1.01 ), neither was sex; age did predict survival, and so did site and stage.

We finally analysed the relationship between SDI and survival in the four site/stage subgroups with over 100 cases. The corresponding age and sex adjusted SDI hazard ratios were as follows: lung, regional, 0.99; lung, disseminated, 1.01; breast, local, 0.97; and breast, regional, 1.00 ( $p>0.45$ in all cases). Hence, even within specific tumour stages, SDI did not appear related to survival time.

\section{Discussion}

The findings provide further evidence of a lack of a consistent relationship between SDI and survival, and of a very weak relationship between SDI and tumour stage at diagnosis. ${ }^{10-26}$ Specifically, in the population served by our hospital, tumour extension at the time of diagnosis did not appear to be significantly influenced by SDI or duration of symptoms (with the exception of breast cancer). No excess risk of mortality associated with longer SDI was observed either: age and sex adjusted hazard ratios were always close to unity. Among the variables analysed, only age, tumour site, and extension were meaningfully related to survival time.

Differences in SDI among tumour sites were quite remarkable, particularly between breast and 
lung neoplasms. This finding seems coherent with the notion that SDI may partially be influenced by the biological behaviour of the tumour. ${ }^{39} 47$ Clinical ("auxometric") measures of tumour growth ${ }^{48-51}$ may, in this respect, be of relevance.

In addition to well known limitations of hospital based tumour registries, ${ }^{5253}$ the following considerations should be taken into account when interpreting the findings. Since it is not always clinically efficient to estimate the exact time of the onset of symptoms, our measure of SDI (which, as mentioned, was estimated from clinical records) was relatively crude. In fact, in a separate study currently underway, based on a structured patient interview targeting SDI phases, ${ }^{54} 55$ we observed slightly longer intervals than those registered based upon clinical notes. Whereas we deem it unlikely that a differential bias favouring any specific subgroup occurred in our study, we cannot rule out the possibility that nondifferential measurement errors (including recall errors) might have obscured a relationship between the duration of symptoms and survival. There is no doubt that more accurate measurements of SDI phases and of tumour stage are needed; with some exceptions, ${ }^{256}$ they are more feasible in specific ad hoc studies than in tumour registry analyses.

One must also seriously consider the possibility that in the low income population here analysed

Table III Cox proportional hazards survival analysis.

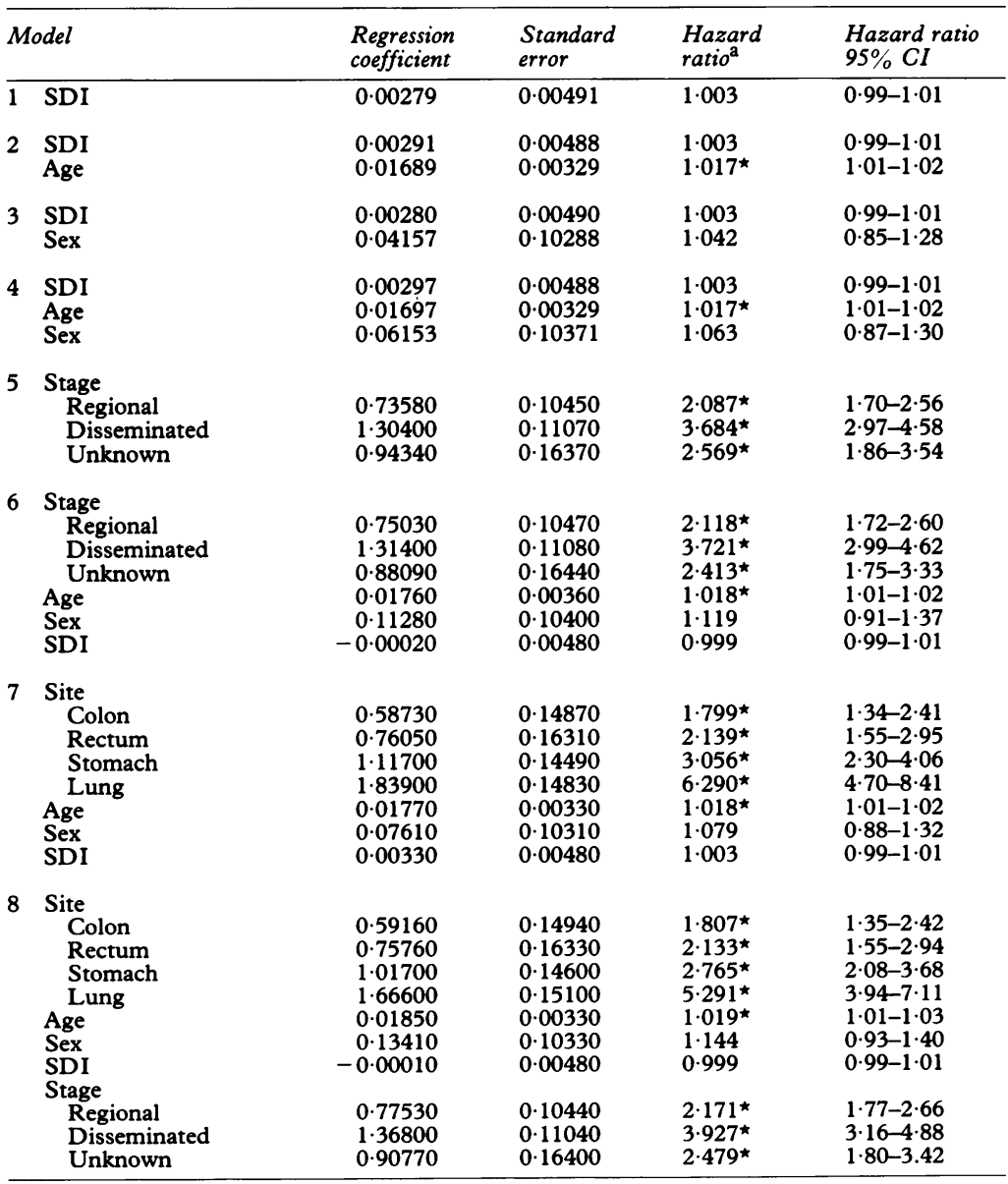

$\mathrm{CI}=$ Confidence interval; SDI = Interval from first symptom to diagnosis
a $\mathrm{Ratio}$ to hazard rates for categories of each variable. The ratio contains the hazard rate for the "unfavourable to survival" category in the numerator and the "favourable to survival" category in the denominator. Favourable or reference categories are female, local stage, and breast site. ${ }^{\star} \mathrm{p}<0.001$ the range of SDI values was actually not wide enough for an effect upon survival to be evidenced.

We analysed a small number of factors. Indeed, we consider the duration of symptoms to be a highly complex variable reflecting patient and physician behaviour, ${ }^{1-381427475758}$ the clinical course, ${ }^{121359}$ the functioning of the health system, ${ }^{1} 681447$ sociocultural values, $555860-65$ and tumour biology. ${ }^{131434}{ }^{49}$ Certainly, the many variables likely to mediate the SDI-prognosis relationship are not easy to measure accurately in large numbers of patients. Still, epidemiological analyses which meaningfully integrate the different clinical, biological, and psychosocial factors involved are much in need. ${ }^{66}$

Even though several subgroups here analysed have small numbers, the study allowed comparison of the five more frequent tumours (accounting for over half of all cancer cases) in most developed countries. While it is not implausible that differences in prognosis between SDI subgroups might be uncovered by an analysis based on a larger number of cases, we think it unlikely that their magnitude is large.

It is also worth emphasising that the primary goal of the current analysis was to assess the relationship between SDI and tumour stage, and between SDI and survival, rather than to identify a model that would fit the data.

Additionally, we suggest that interpretation of the present results may also benefit from the following conceptual considerations. Prognosis of many tumours appears to be largely influenced by factors active in the presymptomatic phases of the illness, the symptomatic phase often representing a much smaller fraction of the natural history of the malignancy. ${ }^{34}{ }^{67-69}$ Accordingly, variations in SDI might account for only a limited portion of differences in stage at diagnosis, and of differences in survival. The group of patients presenting within a short time after onset of symptoms is likely to comprise a mixture of patients with more virulent tumours and of patients with less biologically active tumours but seeking care sooner. Conversely, patients presenting long after onset of symptoms may include patients with relatively benign tumours as well as patients with more agressive disease who greatly delay seeking care. It is the biological and clinical heterogeneity of patients with similar SDI that makes this interval somewhat misleading (though fascinating). In fact, it is possibly an error to focus exclusively on the (quantitative) time dimension: clinical (qualitative) changes experienced during tumour progression have been found to be an independent determinant of prognosis. ${ }^{48-51}$

In our view, a relevant question to pose is: does tumour behaviour influence patient behaviour or is it the other way round? Our hypothesis is that two simultaneous processes interact: (a) the promptness with which a person seeks medical attention and the specific medical path he or she follows influence the stage at which cancer is diagnosed, and the subsequent disease course; and (b) in turn, the biological and clinical behaviour of the tumour influence both the patient's perception, assessment, and response to symptoms, and the pathway followed among the 
several usually available within a health care system. The resulting SDI, duration of symptoms, or "progression interval"49 (terms we deem more neutral and appropriate than diagnostic "delay") is also modified by psychosocial factors (such as patient's personality, education, income, and access to care) and by other environmental factors (eg, the prevalence of cancer influences the predictive value of clinical signs, thus determining physician's diagnostic accuracy. ${ }^{70}$ ) An elaboration of this model is beyond the scope of this paper.

Given that the rate of tumour growth is commonly related both to survival and to the likelihood of SDI reduction (slower growing tumours being more amenable to early clinical detection), 27333469 evaluators of early clinical detection programmes should consider the potential for clinical length bias and clinical lead time bias to occur. Early detection must be measured in terms of tumour stage rather than duration of symptoms.

Although the idea that many cancers are curable if discovered early in the clinical course is clinically appealing, and in spite of solid scientific evidence that high quality screening programmes improve prognosis of some cancers, ${ }^{2733} 3471$ the present results show that in a particular population group observed under natural conditions, the interval from first symptom to diagnosis very weakly influences the spread of the tumour at the time of diagnosis, and does not affect survival beyond the effect of stage at diagnosis. In our view, this cannot be taken to imply that specific interventions aimed at speeding up diagnosis in individuals are ineffective. There undoubtedly is an ethical obligation to detect, diagnose, and treat promptly individuals presenting with symptoms. Furthermore, diagnostic and treatment delays caused by malfunctioning of the health system must be reduced. Yet from a public health perspective one question remains: how wide a community impact in terms of mortality reduction can a decrease in SDI have? While secondary prevention undoubtedly has a role in medical care, findings such as ours emphasise some limitations within which it operates. ${ }^{71}$ More efforts should be devoted towards the discovery of better tools for presymptomatic detection of cancer. Primary prevention remains the outstanding top priority for cancer control.

This work was partially made possible by grants from the Fondo de Investigación Sanitaria (No 88/2794, No 88/0564) and from the Institut Municipal d'Investigacio Mèdica (IM875138/9). The authors are also grateful to Robert $\mathrm{H}$ Fletcher for scientific advice, and to Debbora Barnes, Rosa Arboix, Jordi Alonso, and David MacFarlane for technical assistance.

Presented to the 1990 Regional European meeting of the International Epidemiological Association (IEA), Granada, Spain, 14-16 February 1990.

1 Rowe-Jones DC, Aylett SO. Delay in treatment in carcinoma of colon and rectum. Lancet 1965; ii: 973-6.

2 MacArthur C, Smith A. Factors associated with speed of diagnosis, referral, and treatment in colorectal cancer. $f$ Epidemiol Community Health 1984; 38: 122-6.

3 Funch DP. The role of patient delay in the evaluation of breast self-examination. $\mathcal{f}$ Psychol Oncol 1984; 2: 31-33.
4 Robinson E, Mohilever J, Zidan J, Sapir D. Colorectal cancer: incidence, delay in diagnosis and stage of disease. Eur $f$ Cancer Clin Oncol 1986; 22: 157-61.

5 Akdas A, Kirkali Z, Remzi D. The role of delay in stage-III testicular tumours. Eur Urol 1986; 12: 151-3.

6 GIVIO (Interdisciplinary group for cancer care evaluation). Reducing diagnostic delay in breast cancer. Possible therapeutic implications. Cancer 1986; 58: 1756-61.

7 Robbins GF, Conte AJ, Leach JE, Macdonald M. Delay in diagnosis and treatment of cancer. $\mathscr{f} A M A$ 1950;143 $346-8$.

8 Robinson $\mathrm{E}$. The fight against delay in the diagnosis of cancer. Biomed Pharmacother 1984; 38: 321-2.

9 Oliver RTD. Factors contributing to delay in diagnosis of testicular tumours. BMf 1985; 290: 356

10 Brookes VS, Waterhouse JAH, Powell DJ. Carcinoma of the stomach: a 10-year survey of results and of factors affecting prognosis. BMf 1965; i: $1577-83$.

11 Keddie N, Hargreaves A. Symptoms of carcinoma of the colon and rectum. Lancet 1968; ii: 749-50.

12 Lim BS, Dennis CR, Gardner B, Newman J. Analysis of survival versus patient and doctor delay of treatment in gastrointestinal cancer. Am f Surg 1974; 127: 210-4.

13 Irvin TT, Greaney MG. Duration of symptoms and prognosis of carcinoma of the colon and rectum. Sur Gynecol Obstet 1977; 144: 883-6.

14 Holliday HW, Hardcastle JD. Delay in diagnosis and treatment of symptomatic colorectal cancer. Lancet 1979; i: 309-11.

15 Pescatori M, Mingrone G, Maria G. Delay in diagnosis of colorectal cancer. Lancet 1979; i: 1137 .

16 Bassett ML, Bennett SA, Goulston KJ. Colorectal cancer. A study of 230 patients. Med $\mathcal{F}$ Aust 1979; 1: 589-92.

17 McDermott F, Hughes E, Pihl E, Milne B, Price A. Symptom duration and survival prospects in carcinoma of the rectum. Surg Gynecol Obstet 1981; 153: 321-6.

18 Pescatori M, Maria G, Beltrani B, Mattana C. Site, emergency, and duration of symptoms in the prognosis of colorectal cancer. Dis Colon Rectum 1982; 25: 33-40.

19 Jolly KD, Scott JP, MacKinnon, Clarke AM. Diagnosis and survival in carcinoma of the large bowel. Aust NZ $\mathcal{F}$ Surg 1982; 52: 12-6.

20 Maté Jiménez J, Carbó Perseguer J, Rodriguez Muñoz S, Pajares García JM. Influencia de la demora diagnóstica, edad y diferencianción tumoral de los adenocarcinomas de colon sobre el pronóstico de los mismos. Rev Esp Enferm Digest 1986; 69: 417-9.

21 Fowler WC, Freeman AC, Hulka BS, et al. Delays in cervical cancer treatment: an assessment of patient and provider characteristics. In: Advances in cancer control: epidemiology and research. New York: Alan R Liss, 1984

22 Robinson E, Mohilever J, Zidan J, Sapir D. Delay in diagnosis of cancer. Possible effect on the stage of disease and survival. Cancer 1984; 54: 1454-60.

23 Sneppen O, Hansen LM. Presenting symptoms and treatment delay in osteosarcoma and Ewing's sarcoma. Acta Radiol (Oncol) 1984; 23: 159-62

24 Melamed MR, Flehinger BJ, Zamon MB, Healen RT, Perchick WA, Martini N. Screening for early lung cancer. Results of the Memorial Sloan-Kettering study in New York. Chest 1984; 86: 44-53.

25 Smith EM, Anderson B. The effects of symptoms and delay in seeking diagnosis on stage of disease at diagnosis amon women with cancers of the ovary. Cancer 1985; 56: 2727-32

26 Graffner H, Olsson SA. Patient's and doctor's delay in carcinoma of the colon and rectum. $\mathcal{F}$ Surg Oncol 1986; 31. 188-90.

27 Saracci R. Neoplasms. In: Holland WW, Detels R, Knox G eds. Oxford textbook of public health, Vol 4 . Oxford: Oxford eds. Oxford textbook of public healt

28 LaMont JT, Isselbacher KJ. Diseases of the small and large intestine. In: Petersdorf RG, Adams RD, Braunwald E, Isselbacher KJ, Martin JB, Wilson JD, eds. Harrison' principles of internal medicine, 10th ed. New York: McGraw-Hill, 1983: 1752-65.

29 Ruddon RW. Cancer biology, 2nd ed. New York: Oxford University Press, 1987

30 Liotta LA, Stetler-Stevenson WG. Principles of molecular cell biology of cancer: cancer metastasis. In: DeVita VT Hellman S, Rosenberg SA, eds. Cancer. Principles and practice of oncology, 3rd ed. Philadelphia: Lippincott, 1989: practice

31 McDermott FT, Hughes ESR, Pihl E, Milne BJ, Price AB. Prognosis in relation to symptom duration in colon cancer. Br f Surg 1981; 68: 846-9.

32 Myers WPL. Cancer and Internal Medicine: an internist's approach to cancer and its medical manifestations. In Beeson PB, McDermott W, Wyngaarden JB, eds. Ceci textbook of medicine, 15th ed. Philadelphia: WB Saunders, 1985: 1898-907.

33 Hulka BS. Screening for cancer: lessons learned. 7 Occup Med 1986; 28: 687-91.

34 Morrison AS. Screening in chronic disease. New York: Oxford University Press, 1985: 13.

35 Nowell PC. Molecular events in tumour development (editorial). N Engl f Med 1988; 319: 575-7.

36 Kerr IB. Molecular genetics of colorectal carcinoma (editorial) $B M \mathcal{F} 1989$; 299: 637-8.

37 Roberts AB, Sporn MB. Principles of molecular cell biology of cancer: growth factors related to transformation. In: of cancer: growth factors related to transformation. In: Drinciples and practice of oncology, 3rd ed. Philadelphia:
Prita Lippincott, 1989: 67-80. 
38 Planas J, Gallén M, Malats N, Porta M, Guasch I. Registro de tumores del Hospital del Mar (Barcelona). Análisis descriptivo 1978-1986. Rev Clin Esp 1988; 183: 175-9.

39 Porta M, Gallén M, Planas J, Malats N. El intervalo sintoma-diagnóstico: una aproximación posible a la historia natural de las neoplasias. Rev Sanid Hig Publica (Madr) natural de las neopl

40 Viladiu P, Beltran M, Monrás P, Bosch FX, Martin M. Registre de tumors. Servei d'Oncologia de l'Hospital Provincial de Sta. Caterina de Girona. Análisi general. Gac Sanit 1983; 2: 230-6.

41 Kaplan EL, Meier P. Nonparametric estimation from incomplete observations. F Am Stat Assoc 1958; 53: 457-81.

42 Gehan EA. A generalised Wilcoxon test for comparing arbitrarily singly-censored samples. Biometrika 1965; 52: 203-23.

43 Lee ET, Desu MM. A computer program for comparing k-samples with right censored data. Comput Prog Biomed 1972; 2: 315-21.

44 Cox DR. Regression models and life-tables. $f R$ Stat Soc / $/ 1972 ; 34: 187-220$.

45 Lubin J, Storer B, Setzer RW. Pecan user's manual, version 3.03. Chapel Hill, NC: School of Public Health, University of North Carolina, 1986

46 Harrell FE. The PHGLM procedure. SUGI supplemental library user's guide. Version 5 ed. Cary, NC: SAS Institute, Inc., 1986: 437-66.

47 Porta M, Belloc J, Malats N. Estudios españoles sobre la demora diagnóstica y terapéutica en el cáncer. Un análisis critico de su metodologia y resultados. In: Porta $\mathbf{M}$, Alvarez-Dardet C, eds. Revisiones en Salud Pública, 1 . Alvarez-Dardet C, eds. Revisiones

48 Feinstein AR. A new staging system for cancer and a reappraisal of "early" treatment and "cure" by radical surgery. N Engl f Med 1968; 279: 747-53.

49 Charlson ME, Feinstein AR. A new clinical index of growth rate in the staging of breast cancer. $A m \mathcal{F} \mathrm{Med} 1980$; 69: 527-36.

50 Feinstein AR, Wells CK. Lung cancer staging: a critical evaluation. Clin Chest Med 1982; 3: 291-305.

51 Wells CK, Stoller JK, Feinstein AR, Horwitz RI. The prognostic impact of symptoms and comorbidity in the prognostic impact of symptoms and comorbidity in the 2004-9.

52 MacLennan R, Muir C, Steinitz R, Winkler A. Cancer registration and its techniques. IARC Scientific Publications, No 21. Lyon: IARC, 1978

53 Austin DF. Cancer registries: a tool in epidemiology. In Lilienfeld AM, ed. Reviews in cancer epidemiology, vol 2 . New York: Elsevier, 1983: 118-39.

54 Porta M, Malats N, Belloc J, Gallén M, Planas J. Estudio ambidireccional sobre las causas y las consecuencias del retraso diagnóstico en las neoplasias sintomáticas del tubo digestivo. Resultadas preliminares sobre el cáncer de colonrecto. In: Proceedings of the VII "Reunion Cientifica de la Sociedad Española de Epidemiologia". San Sebastián: SEE, 1988: 54.

55 Malats N, Porta M, Belloc J, Gallén M, Planas J. Predictore de la demanda asistencial de los enfermos afectos de cáncer del intestino grueso. In: Proceedings of the 'VIII Reunión Cientifica de la Sociedad Española de Epidemiologia' Cientifica de la Sociedod

56 MacArthur C, Pendleton LL, Smith A. Treatment delay in patients with bladder tumours. $\mathcal{F}$ Epidemiol Community Health 1985; 39: 63-6.

57 Funch DP. Diagnostic delay in symptomatic colorecta cancer. Cancer 1985; 56: 2120-4.

58 Funch DP. The role of patient delay in the evaluation of breast self-examination. F Psychosoc Oncol 1984; 2: 31-39.

59 MacArthur C, Smith A. The symptom presentation of breast cancer: is pain a symptom? Community Med 1983; 5 : 220-3.

60 MacArthur C, Smith A. Factors associated with speed of diagnosis, referral, and treatment in colorectal cancer. $\mathcal{f}$ Epidemiol Community Health 1984; 38: 122-6.

61 Stavraky KM, Kincade JE, Stewart MA, Donner AP. The effect of socioeconomic factors on the early prognosis of cancer. $\mathcal{F}$ Chronic Dis 1987; 40: 237-44.

62 Twaddle AC. Sickness and the sickness career: some implications. In: Eisenberg L, Kleinman A, eds. The relevance of social science for medicine. Dordrecht: Reidel, 1981: 111-33.

63 Goldsen RK, Gerhardt PR, Vincent HH. Some factors related to patients in seeking diagnosis for cance symptoms. Cancer 1957; 10: 1-7.

64 Hackett TP, Cassem NH, Raker JW. Patient delay in cancer. $N$ Engl F Med 1973; 289: 14-20.

65 Vågerö D, Persson G. Cancer survival and social class in Sweden. F Epidemiol Community Health 1987; 41: 204-9.

66 Susser M. Epidemiology today: "A thought-tormented world". Int $\mathcal{f}$ Epidemiol 1989; 18: 481-8.

67 Upton AC. Principles of cancer biology: etiology and prevention. In: DeVita VT, Hellman S, Rosenberg SA, prevention. In: DeVita VT, Hellman S, Rosenberg SA, Philadelphia: Lippincott, 1982: 33-58.

68 DeVita VT. Principles of cancer therapy. In: Petersdorf RG DeVita VT. Principles of cancer therapy. In: Petersdorf RG, Adams RD, Braunwald E, Isselbacher KJ, Martin JB,
Wilson JD, eds. Harrison's principles of internal medicine, Wilson JD, eds. Harrison's principles of internal medic

69 Fletcher RH, Fletcher SW, Wagner EH. Clinical epidemiology. The essentials, 2nd ed. Baltimore: Williams \& Wilkins, 1988: 157-71.

70 Goulston KJ, Cook I, Dent O, et al. How important is recta bleeding in the diagnosis of bowel cancer and polyps? Lancet 1986; ii: 261-4.

71 Battista RN, Grover SA. Early detection of cancer: an overview. Annu Rev Public Health 1988; 9: 21-45. 